\title{
Vytváření sociologické teorie náboženství
}

\author{
Making Sociological Theory of Religion \\ Dušan Lužný
}

\begin{abstract}
The study is divided into four parts. The first part deals with ways in which sociology (sociology of religion) created a theory of religion, i.e., asks what is the possible strategy of creation sociological theory of religion. This section also contains some important principles that are required for each contemporary sociological theory of religion (e.g. cross-cultural comparison, i.e., formulation of theories, concepts and postulates that are possible and necessary to undergo cross-cultural comparison. The second part summarizes the benefits and insufficiencies of the two major contemporary sociological theories of religion which are the secularization theory and the rational choice theory. The third part presents the most significant sources of inspiration for contemporary theory of religion (cognitive study of religion, cognitive archeology and anthropology, evolutionary psychology and sociobiology). The fourth part presents the author's own attempt to formulate basic propositions for possible bio-cultural theory of religion that is based on the above-mentioned sciences and also incorporates current approaches and findings of sociology of religion, including the theory of secularization theory and the rational choice theory.
\end{abstract}

KEYWORDS sociology of religion, secularization theory, rational choice theory, cognitive study of religions, biocultural theory of religion

Pokud vezmeme vážně otázku po směřování sociologické teorie ${ }^{1}$ a pokusíme se ji aplikovat do oblasti sociologie náboženství, ocitneme se v modelové situaci, která je typická pro všechny vědní disciplíny a týká se vytváření vědeckých teorií. Dramatičnost této situace na jedné straně, ale i její kouzlo na straně druhé, spočívá v tom, že teorie sociologie náboženství (respektive sociologická teorie náboženství) ${ }^{2}$ nemůže být izolovaná od obecné teorie vědy (respektive od obecných principů metodologie vědy a obecných principů „dělání“ vědy), stejně jako od obecné sociální teorie, ale také nemůže být izolována od jiných speciálních

Sociálni studia. Katedra sociologie FSS MU, 1/2012. S. 93-118. ISSN 1214-813X.

1 Autor by rád touto cestou poděkoval recenzentům, jejichž posudky obsahovaly řadu velmi podnětných připomínek. Na některé z nich se autor snažil v konečné verzi textu reagovat, avšak některé $\mathrm{z}$ nich nebylo možno $\mathrm{v}$ textu dostatečně reflektovat, především $\mathrm{s}$ ohledem na jeho rozsah. Autor předpokládá, že bude mít dostatek sil a př́ležitostí se s nimi vyrovnat v nějakém $\mathrm{z}$ dalších svých textů.

2 Tyto dva termíny budu většinou $\mathrm{v}$ tomto textu používat jako synonyma, ačkoliv je $\mathrm{v}$ určitém momentu vhodnějši jejich rozlišování, protože naznačuje, ukazuje a umožňuje analyzovat odlišné strategie vytváření této teorie, respektive teorií. 
vědeckých disciplín, které tematizují náboženství. Jinými slovy: existuje-li, respektive má-li existovat něco, co bychom mohli nazvat sociologickou teorií náboženství, pak její vytváření, základní principy a podoba by měly být (minimálně) srovnatelné s obecnými principy vědeckých teorií (včetně přírodovědeckých), tato teorie by měla korespondovat $\mathrm{s}$ obecnou sociologickou teorií, a také by měla integrovat teoretické diskuse a závěry kulturní a sociální antropologie, historie, politologie, kulturálních studií, religionistiky apod. (k současné diskusi o pojetí akademického studia náboženství srv. např́klad Havlíček 2011: 19-76).

Přijmeme-li tuto perspektivu, stává se teorie jedné konkrétní vědní (sub)disciplíny (v tomto případě sociologie náboženství) nástrojem přeměny a vytváření obecné sociologické teorie. Hned na začátku tohoto textu chci jasně zformulovat dva základní principy, které zastávám při vytváření sociologické teorie náboženství.

Za prvé jsem přesvědčen, že odlišnosti mezi vědami př́rodními a sociálními (či ještě navíc humanitními; respektive vědami „o přírodě“ a vědami o ,člověku“) jsou doposud př́liš dramatizovány a ontologizovány, což má často podobu striktních proklamací o neslučitelnosti bádání o dvou realitách (prŕírodní a lidské). Zdůrazňování specifičnosti „Geisteswissenschaften“ (Dilthey a jeho následovníci) mělo své opodstatnění v době vytváření legitimity sociálních a humanitních věd, dnes však může být spíše zdrojem uzavřenosti, sebestřednosti a neochoty (či neschopnosti) podrobit dosavadní způsoby tvorby poznatků a teorií v sociálních a humanitních vědách širší kritické diskusi, čímž může získanou legitimitu paradoxně oslabovat. To však neznamená popření jakýchkoliv specifik těchto věd, včetně způsobů dělání určitých vědních oborů (např́klad je zř̌jmé, že existuje rozdíl mezi „děláním“ subatomární fyziky, astronomie, demografie a dějin umění). Rozdíl mezi „přírodním“ a „kulturním“ je podle našeho názoru přínosný (v omezené míře) jen za předpokladu, že je chápán jako nástroj analýzy, ne však jako ontologická danost. Proto je také možné dramatičnosti rozporu mezi „vysvětlením“ a ,porozuměním“ př́liš nepodléhat a spíše je chápat jako dva způsoby zacházení s realitou a v sociologické teorii (ale především praxi) s nimi pracovat souběžně (paralelně). Východiskem tohoto prvního principu je tedy pojetí člověka jako bio-kulturní bytosti, v níž se spojují jak prvky biologické, tak prvky kulturní. Konkrétně to znamená, že sociologie může používat jak vysvětlení, tak porozumění, respektive některé aspekty lidského chování a jednání může sociologie „vysvětlovat“ a jiným „rozumět“", a současně může určité sociální jednání zároveň „vysvětlovat"“ i mu „rozumět“, nebot' i ,smysluplné“ sociální jednání může být biologicky (popř́ípadě ekologicky) podmíněno (či výrazně ovlivněno biologickými/ekologickými faktory). V tomto ohledu se může sociologie (náboženství) značně inspirovat u kulturní antropologie (např́klad pojetím Roye A. Rappaporta).

Jestliže přijmeme tento první princip, pak druhý je zcela nevyhnutný: bez ne-sociologických, respektive mimo-sociologických teorií, konceptů a dat se sociologická teorie (náboženství) neobejde, respektive zůstane uzavřena $\mathrm{v}$ omezeném rámci jedné perspektivy a skončí v nekonečném bludném sebestředném kruhu kritiky a rozpracovávání dosavadních konceptů sociologie náboženství, respektive $\mathrm{v}$ neimaginativním rozboru doposud publikovaných textů významných autorů. Tímto však netvrdím, že nová čtení a kritika Marxe, Webera, Durkheima, Simmela, Parsonse, Bergera, Luckmanna, Luhmanna, Martina, Bruce či Starka nejsou možná nebo že nejsou přínosná. Naopak, kritické vyrovnávání se 
s dosavadní tradicí je základem pro vlastní odbornou produkci; jsem však přesvědčen, že je to málo a že více či méně př́buzné obory jsou obrovským rezervoárem inspirace a nástrojem reflexivního budování (dílčí i obecné) sociologické teorie. Navíc čtení klasiků se znalostí současných výsledků bádání různých věd je v mnoha ohledech inspirující. V kontextu této studie by bylo jistě př́nosné „,nové čtení“ Marxe, Webera, Durkheima i Parsonse; na to však v textu není místo.

$\mathrm{Na}$ následujících řádcích se pokusím tento přístup ilustrovat na příkladu teoretizování $\mathrm{v}$ rámci sociologie náboženství a ukázat alespoň některé inspirační mimo-sociologické zdroje, se kterými by se podle mého názoru měla sociologie náboženství, ale také sociologie jako celek, vyrovnat.

\section{Sociokulturní kontext teoretizování}

Tvrzení, že sociologická teorie nevzniká ve vzduchoprázdnu, ale v určitém historickém, sociálním a kulturním kontextu, je na první pohled či poslech (zvláště pro sociology a socioložky) banální. Avšak málokdy se od této banality vydáme ke konkrétní analýze sociokulturního rámce a kontextu vytváření sociologické teorie (srv. například Váně 2010). Existuje samožrejmě v sociologické obci tradovaná souvislost mezi parsonsovským funkcionalismem a klimatem hospodářského rozvoje a politické stability americké společnosti 50 . let nebo mezi oblibou perspektivy sociologie konfliktu a změny v dramatickém období kontrakulturního experimentování 60 . let. Mưžeme také poukázat na objevení se tématu náboženství v sociologickém uvažování ve třetí čtvrtině minulého století, které bezesporu souvisí s náboženským oživením, ke kterému došlo v USA, a s pronikáním náboženství do veřejného prostoru, respektive s rolí, které náboženství hrálo v některých politických událostech (nárůst politického vlivu konzervativní křest’anské pravice v USA, popularita teologie osvobození v Latinské Americe, snaha o aktivnější komunikaci s okolním světem a o modernizaci římsko-katolické církve po Druhém vatikánském koncilu, působení Jana Pavla II. jako významného globálního a mediálního aktéra, islámská revoluce v Íránu, prosazení se náboženského nacionalismu v řadě zemí světa, sílící náboženský fundamentalismus a upevňování etnicko-náboženské identity jedinců i skupin, „střet civilizací“ a propojování tématu náboženství $\mathrm{s}$ tématem globálního terorismu apod.).

Podíváme-li se na tyto události a okruhy témat, můžeme identifikovat jeden významný proces, který by se měl stát součástí reflexivního vytváření sociologické teorie náboženství. Je jím globalizace, kterou bychom na tomto místě mohli s velkým (ale nutným) zjednodušením vymezit jako proces vytváření světa jako jednoho místa (Robertson 1992). Skutečnost globality s jejími různými podobami a rovinami nutně vede $\mathrm{k}$ silnější artikulaci některých témat a k posilování určitých metodologických principů ve výzkumu náboženství a v teoretickém zarámování sociologie náboženství (viz např́ílad Beckford 2003; Turner 1990, 1991, 1994; Beyer 1994, 2006; Beyer a Beaman 2007; srv. též Lužný 2010a: 13-18, 2010c). Tím nejvýraznějším a dosud nedostatečně reflektovaným důsledkem globality pro sociologii náboženství je požadavek mezikulturní komparace, respektive požadavek formulovat teorie, rozpracovávat koncepty a vytvářet, uspořádávat a interpretovat data tak, aby je bylo možno podrobit mezikulturní komparaci. Dnes je stále více a více zřejmé, že velká 
část dosavadní sociologické tradice (včetně klasické sociologie) se pohybovala (a doposud pohybuje) v rámci euroamerického (,západního“) způsobu nahlížení světa a myšlení o něm. Tato skutečnost není ničím překvapujícím, nebot' každý obraz světa, každé „poznání“, každé uvažování, a tedy i každé sociologizování, je dobově a kulturně podmíněné. Problémem však je, když se tak děje nereflexivně a sociologie se stává (dobrovolně a zbytečně) součástí produkce či reprodukce partikulárních etnocentrismů, které by přitom měla sama studovat a rozkrývat.

Klasickým př́íkladem takového sociologií silně podporovaného konceptuálního etnocentrismu je používání termínů „církev“ a „sekta“. Pokud je totiž budeme chtít použít na jiné náboženské tradice, budeme do reality vnášet něco, co tam není (např́iklad pokud se budeme snažit analyzovat hinduismus či taoismus za pomoci tohoto teoreticko-konceptuálního aparátu), nebo budeme muset radikálně předefinovat kategorie. Obě tato řešení nejsou vhodná, takže jediný způsob, jak se s tímto problémem uspokojivě vypořádat, je rezignovat na dosavadní kategoriální aparát, což však znamená vytvořit i jinou teorii náboženství. Obdobné je to i s další klíčovou kategorií dosavadní sociologie náboženství, kterou je konverze. Zatímco u dichotomie sekta-církev lze lehce rozpoznat katolické kulturní kořeny (sekta jako společenství heretiků či odpadlíků od církve), v př́ípadě konverze jde o kořeny protestantské (zde má individuální konverze vysokou hodnotu, zatímco u katolíků má hodnotu malou, protože „katolíkem se člověk rodí“, svoji náboženskou příslušnost získává narozením a křest jistě není důsledek osobního rozhodnutí jedince - batolete). Také v př́ípadě řady dalších náboženských tradic (od judaismu přes hinduismus až po šintó) lze jen s velkými obtížemi (pokud vůbec) hovořit o konverzi. Východiskem by mohlo být nahrazení těchto kulturně (hodnotově) zatížených termínů jinými. Např́íklad termíny „sekta“ a „kult"“ by mohly být nahrazeny po vzoru antropologie termínem „enkláva“ a termín konverze by po vzoru Bergera a Luckmanna (ze Sociální konstrukce reality) mohl být nahrazen obecnějším ,alternace“. Otázkou je, zda by nový kategoriální aparát našel v sociologické obci dostatečnou podporu, nebot' je obecně známo, že vědecké komunity bývají v tomto ohledu dosti konzervativní a tradicionalistické.

Reálná existence (i vnímání) světa jako ,jednoho místa“ má pro akademické studium náboženství výrazné dopady. Tím nejdůležitějším je otevření tématu náboženské rozdílnosti a existence „společného základu“ všech náboženství. Jinak řečeno, globalita posiluje význam otázky po existenci nějaké náboženské podstaty člověka. Pro sociologii je takto formulované téma značně „metafyzické“, a proto vůči němu existuje v sociologické obci značná nedůvěra. Navíc je zřejmé, že zde si sociologie nevystačí pouze s vlastními př́ístupy a postupy a že bude muset vyjít vstříc jiným vědním disciplínám, na které sociologové často pohlížejí s přezíravostí (klasickým příkladem je sociologické přezírání psychologie a nedůvěra vůči ní).

Podívejme se tedy nyní, jak se s otázkou globality, náboženské různorodosti, popřípadě religiozní povahy člověka vyrovnávají dva dosavadní dominantní teoretické přístupy sociologie náboženství. 


\section{Teorie sekularizace a teorie (racionální) volby}

$\mathrm{V}$ centru pozornosti teorie sekularizace ${ }^{3}$ je vztah mezi modernitou a náboženstvím. Jakkoliv existuje řada pojetí teorie sekularizace, lze říci, že základem těchto teorií (například Wilson 1992, Berger 1967, Martin 1978, Bruce 1996) je tvrzení, že v důsledku nástupu modernity a modernizačních procesů je dosavadní postavení náboženství znejistěno, respektive že $s$ př́íchodem moderní společnosti se mění postavení náboženství. Někteří autoři jsou přesvědčení o systémové nekompatibilitě náboženství a moderní společnosti a tvrdí, že ve všech moderních společnostech dochází $\mathrm{k}$ poklesu sociálního významu náboženství, jiní toto tvrzení zmírňují tím, že tento pokles sociální významnosti přisuzují pouze tradičním formám náboženství, další pak hovoří o odklonu od institucionálních forem náboženství (přičemž tím většinou míní odklon od tradičních zavedených církví) nebo o ztrátě veřejného významu náboženství a jeho zatlačení do sféry soukromí. Sekularizace je pak nahlížena jako důsledek obecnějších modernizačních procesů, především urbanizace, industrializace a strukturální diferenciace, a teorie sekularizace je tak vlastně jen částí obecné teorie modernizace.

Již při prvním pohledu na teorii sekularizace je zřejmé, že se jí daří vysvětlit některé posuny a změny, ke kterým skutečně v moderní společnosti došlo; avšak jsou také patrné její omezení a nedostatečnosti. Tou nejvýraznější je její etnocentrismus, respektive skutečnost, že vznikla jako zobecnění některých procesů a podmínek, které jsou však výrazně časově a prostorově omezeny. Základní kameny teorie sekularizace totiž odpovídají jen části historické zkušenosti některých evropských společností po osvícenství, respektive tyto kameny jsou součástí specifické kulturní paměti Evropy a z různých stran odrážejí jedno základní téma, kterým je vztah státu a náboženství. Ten v evropských podmínkách získal naprosto specifickou podobu vztahu státu (světské moci, která se obejde bez transcendentního a nadpririrozeného způsobu legitimizace) a jednoho náboženského organizačního uskupení (ř́mskokatolické církve, která od jisté chvíle ztělesňovala propojení světské moci a moci náboženské, jež legitimitu své moci odvozuje od mimosvětského a nadsvětského zdroje). $Z$ tohoto pohledu je tedy oprávněné hovořit o procesu sekularizace (a o teorii sekularizace jako způsobu popisu a analýzy tohoto procesu) jako o dlouhodobé snaze narušit (až odstranit) mocenský monopol jedné náboženské organizace.

Tato historizace úvah o teorii sekularizace má dvojí dopad. Na jednu stranu se díky ní diskuse o sekularizaci vysvobozuje z pout, která ji svazují s procesem modernizace, a teorie sekularizace již nemusí být vnímána jen a pouze jako součást obecněǰśí teorie modernizace. Jinými slovy: otevírá možnosti tematizovat modernizaci (poprípadě různé modernizace) bez spojitosti se sekularizací. Na druhou stranu takovéto historizující pojetí sekularizace ještě více připoutává proces sekularizace $\mathrm{k}$ ojedinělé historické zkušenosti Evropy a výrazně snižuje obecný záměr teorie sekularizace vysvětlit náboženskou změnu v jiných částech světa (například již jen proto, že $\mathrm{v}$ žádné jiné náboženské tradici neexistuje jedna tak mocensky dominantní organizace s úzkým napojením na státní moc). ${ }^{4}$

3 Srv. Vido (2012). Některé aspekty teorií sekularizace, ale též teorie racionální volby také v Lužný (1999).

4 To samozřejmě neznamená, že by v jiných kulturních kontextech neexistovaly mocné náboženské organizace (naprríklad gelugpa $\mathrm{v}$ tibetském buddhismu), nebo že by na řadě míst nedocházelo 
Pokud si podržíme tuto historizující perspektivu a perspektivu, která hledá základní dynamiku sekularizace ve vztahu státu a církve, pak můžeme získat dobrý potenciální nástroj analýzy odlišné podoby sekularizace a intenzity náboženského života (popř́padě důvěry vůči náboženství) v různých moderních a modernizujících se evropských zemích. Jinými slovy: jak je možné, že existují tak výrazné rozdíly v náboženských deklaracích typu ,jsem věřícíc či „věřím v Boha jako osobu“ apod. mezi obyvateli sousedních států nebo společností, které mají mnoho společného ve svých dějinách a kultuře (například rozdíly mezi obyvatelstvem České republiky, Slovenska, Polska, Rakouska či Německa)? Vhodným vysvětlením je zohlednění odlišného postoje dominantního náboženského subjektu (tedy římskokatolické církve) k modernizačnímu procesu (včetně dvou moderních ideologií, kterými jsou liberalismus a socialismus) a k procesu formování národa a národního (sekulárního) státu.

Tyto skutečnosti (včetně specifické situace v jednotlivých zemích po Reformaci) mohou vysvětlit lokální specifika, avšak vedle nich existují některé obecné procesy, které tvoří základ procesu sekularizace. Jsou jimi (dle současného největšího obhájce teorie sekularizace Steva Bruceho) diferenciace, societalizace a racionalizace. Diferenciací můžeme rozumět fragmentalizaci sociálního života do specializovaných rolí a institucí. Ilustrativním př́kladem může být diferenciace, která nastala v oblasti rodiny, kdy se postupem času vyčlenily jednotlivé funkce (ekonomická, reprodukční, výchovná apod.) a původní jednota rodiny byla narušena. $\mathrm{V}$ oblasti náboženství došlo $\mathrm{k}$ obdobnému procesu: původní jednota církve (respektive jejích funkcí jako například vzdělávací, ochrany zdraví, sociální kontroly apod.) se rozpadla do jednotlivých specializovaných institucí. Strukturální diferenciace byla následována diferenciací sociální a vznikly společenské třídy, což mělo mimo jiné za důsledek rozpad věrohodnosti jediného morálního univerza a rozbití morálního a nadpřirozeného řádu, nebot' jednotlivé soutěžící partikulární skupiny si vytvořily vlastní morální priority. Societalizace znamená, že život je stále více organizován ne na základě lokálních společenstev, ale na základě společnosti, respektive (národního) státu. Ten však již nemůže být postaven na jedné (byt' univerzalistické) náboženské tradici, ale musí být nábožensky neutrální, což vede k vytvoření prostoru soutěžení pro jednotlivá náboženství, která si však již nemohou nárokovat univerzální platnost, ale jen dílčí věrohodnost. Racionalizace zahrnuje změny ve způsobu myšlení a v důsledku toho i jednání lidí. Její počátky leží ve starověkém judaismu a raném křest'anství, v průběhu dějin se dále rozvíjely a prohlubovaly a vyústily v různé snahy po dosažení co nejvyšší technické účinnosti prostředků zajištujících pozemské (this-wordly) cíle (Bruce 1999: 8-15).

Z hlediska cílů našeho textu je důležité, že Bruce odmítá univerzalistické nároky (či naopak očekávání) sekularizační teorie a zastává názor, že sekularizace je výsledek specifických podmínek, které nastaly v určité době na Západě. Avšak tyto podmínky nebyly nahodilostí a v okamžiku, kdy nastanou v jiném prostředí, dojde ke stejným důsledkům, tedy k sekularizaci. Zde je namístě poznamenat, že všechny tyto termíny (sekularizace,

k úzkému propojení státní moci s náboženstvím. Tyto vztahy však měly v řadě ohledů jiný charakter (např́íklad v důsledku toho, že nebyly postaveny na monoteismu; a naopak v monoteistických kulturách judaismu a islámu neexistuje taková centralizace náboženské moci, jako je tomu v ř́mském katolicismu). 
diferenciace, societalizace, racionalizace) je nutno chápat jako ideální typy. Tento př́istup nám pak umožňuje vymanit se ze zajetí historické paměti Evropy a pokoušet se sekularizační teorii ověřit globálně (interkulturně).

Odlišný způsob vytváření teorie představuje teorie racionální volby a její sociologická aplikace na téma náboženství. Zatímco teorie sekularizace se snaží zobecnit specifickou situaci západní Evropy v určitém časovém období, a představuje tak spíše induktivní strategii výstavby teorie, teorie racionální volby usiluje o vytvoření obecné sociologické teorie náboženství deduktivním způsobem s cílem ustanovit nové paradigma sociologie náboženství, které sice zahrnuje analýzu vztahu náboženství a (moderní) společnosti, ale jádrem takto zaměřené obecné teorie je určité pojetí člověka a lidského chování a jednání. Díky této strategii se takto vytvořená teorie chce srovnávat s jinými (skutečně) vědeckými teoriemi (což jsou především teorie přírodovědecké), protože teorie racionální volby v rámci sociologie náboženství je souborem jasně a jednoznačně vymezených axiomů, definic a tvrzení (propozic), která lze ověřovat, či vyvracet. Teorie je tedy „soubor tvrzení o vztazích mezi řadou abstraktních konceptů. Tato tvrzení říkají, jak a proč tyto koncepty spolu vzájemně souvisejí. Mimoto, tato tvrzení musí vést k vývodům (implikacím), které mohou být empiricky falzifikovány. Musí tedy existovat možnost vyvodit z teorie určitá tvrzení o empirických událostech, přičemž tato tvrzení se mohou ukázat jako chybná“ (Stark a Bainbridge 1987: 13). Deduktivní teorie sestávají z malého množství základních principů, na které mohou být různé skupiny komplexních fenoménů redukovány. Jde o to najít relativně malý soubor pravidel, která ř́ikají, jak určité významné části reality fungují. Logické permutace těchto pravidel (neboli axiomů) vyvolávají řadu derivátů (čili tvrzení, propozic). Alespoň některá z těchto tvrzení budou mít empirické implikace; budou předpovídat existenci či neexistenci určitých vztahů mezi empirickými indikátory konceptů obsažených v teorii (tamtéž).

Ilustrujme si tento př́stup na několika základních axiomech, definicích a propozicích první verze teorie náboženství Rodneyho Starka a Williama Bainbridge. ${ }^{5}$ První axiom (A1) zní: „Lidské vnímání a jednání se odehrává v čase, od minulosti do budoucnosti.“ Následuje definice (Def. 1): „Minulost se skládá z univerza situací, které mohou být známy, ale nemohou být ovlivněny“ a definice (Def. 2): „Budoucnost se skládá z univerza situací, které mohou být ovlivněny, ale nejsou známy.“ Druhý axiom (A2) již zakládá teorii racionální volby a zní: „Lidé vyhledávají to, co vnímají jako odměny, a vyhýbají se tomu, co vnímají jako náklady“, přičemž odměny jsou definovány (Def. 3) takto: „Odměny jsou všechno to, pro co jsou lidé ochotni podstoupit náklady“ a náklady jsou definovány (Def. 4) následovně: „Náklady jsou cokoliv, čemu se lidé snaží vyhnout.“ Z axiomu A1 a definic Def. 3 a Def. 4 lze vyvodit tvrzení (P1): „Odměny a náklady jsou komplementární: ztracené či ušlé

Tato teorie se vyvíjela v čase. Její základy můžeme najít v publikaci The Future of Religion (Stark a Bainbridge 1985), avšak její první ucelená verze byla představena v $A$ Theory of Religion (Stark a Bainbridge 1987). Tuto teorii pak rozpracovávali Rodney Stark, William Bainbridge, Roger Finke, Laurence Iannaccone v řadě dalších monografií a studií. Zde připomeňme především Acts of Faith. Explaining the Human Side of Religion (Stark a Finke 2000) a Rational Choice Theory and Religion. Summary and Assessment (Young 1997). 
odměny se rovnají nákladům, a náklady, kterým se podařilo vyhnout, jsou odměnami“ (Stark a Bainbridge 1987: 27).

Z těchto jednoduchých základů pak Stark a Bainbridge vytvářejí poměrně složitou vzájemně propojenou stavbu obecné teorie náboženství, kterou lze použít jako nástroj pro další analýzu dílčích témat. Jádrem celé stavby je téma jednání, které je v oblasti sociologie náboženství převedeno do podoby tématu náboženského závazku (religious commitment), protože náboženství je vždy záležitostí skupinovou. Také proto je velká část teorie tvořena tématem náboženských organizací (církev, sekta, kult) a konverzí, tedy okruhy náboženského života, které výrazným způsobem ilustrují vzájemnost jednání, interakci, vazbu jedince na jiné lidi nebo skupinu, sociální soudržnost apod. Je pochopitelné, že se v této teorii odráží do té doby nejvýraznější teorie náboženství, tedy teorie sekularizace, avšak již od počátku obsahuje teorie racionální volby polemiku s teorií sekularizace. Nicméně ve své první verzi (Stark a Bainbridge 1987) neodmítají autoři teorii sekularizace nijak ostře: „Sekularizace je dominantním trendem ovlivňujícím náboženství v současných industriálních společnostech a badatelé často předpokládají, že to znamená ne jenom úpadek, ale zánik všech náboženství [...] my vysvětlíme, že sekularizace znamená transformaci náboženství, ne jeho destrukci“ (Stark a Bainbridge 1987: 279). Je pochopitelné, že obecná teorie náboženství (i v podobě teorie racionální volby) ústí do vysvětlení současného stavu náboženského života (především v moderních společnostech) - snížení moci církví, pluralizace, snadnost denominačních přestupů (konverzí) a neutuchající lidská touha po nedosažitelném uspokojení vede k tomu, že jedním z důsledků sekularizace je rozkvět náboženství. Sekularizace vyvolává náboženské oživení a experimentování (Stark a Bainbridge 1987: 304).

Je pochopitelné, že se v průběhu času stavba této obecné sociologické teorie náboženství mění, i když některé základní kameny zůstávají. Jedním z nejviditelnějších rozdílů je naprosté odmítnutí teorie sekularizace hlavním tvůrcem teorie racionální volby Rodneym Starkem v roce 1999 (Stark 1999, též 2000: 57-79) a explicitní a hlasitá snaha vybudovat nové paradigma sociologie náboženství. V jiné rovině (z hlediska tohoto textu, který primárně nesleduje vzájemnou polemiku mezi stoupenci teorie sekularizace a teorie racionální volby) je posun v teorii racionální volby zajímavější, nebot' odhaluje možnosti využití teorie racionální volby v odlišně pojaté sociologické teorii náboženství, která se snaží mimo jiné využít př́nosných prvků obou soupeřících teorií a propojit ji s jinou oblastí teoretického studia náboženství (což je cílem tohoto textu).

Prvním výrazným posunem je větší důraz na „ekonomickou“ rovinu teorie racionální volby. Ta je samozrejmě sama o sobě dostatečně prodchnuta ekonomickým myšlením, ekonomickými kategoriemi a metaforami. Nicméně ve své druhé verzi teorie náboženství Stark s Finkem tento prvek ještě více posilují a používají jako jednu z centrálních kategorií termín „náboženská ekonomika“, což jim mimo jiné umožňuje analyzovat rozdílnou náboženskou situaci v USA a Evropě. Náboženská ekonomika je totiž založena na soutěžení (trhu), svobodném působení jedinců i skupin (firem), demonopolizovaném náboženském prostředí a pluralismu. V tomto ohledu se Evropa velmi odlišuje od USA a je zřejmé, že teoretici racionální volby považují tržní náboženskou situaci v USA za přirozenou a normální, respektive každou jinou situaci považují za deformovanou. Je příznačné, že teorie racionální volby sílí a získává význačné až dominantní pozice v různých vědách v době, kdy v USA a dalších 
částech světa posiluje politický neoliberalismus. Jak poznamenal Gregory D. Alles: „Stark není pouze Američan, ale je zjevný reaganovec“" (Alles 2009: 83).

Přestože ekonomický a pragmatický př́istup teorie racionální volby (náboženství jako chování racionálních, dobře informovaných aktérů, kteří se rozhodují konzumovat náboženské komodity stejným způsobem, jako když váží náklady a zisky při konzumování sekulárních komodit - Stark, Finke 2000: 42-43) nemusí vyhovovat jemnocitu spíše hermeneuticky založených evropských autorů, a také (což je důležitější) tuto teorii teprve čeká tvrdé interkulturní testování (např́klad aplikace postulátů a závěrů teorie v prostředí islámských zemí nebo v Indii, Č́ně, Japonsku či Africe), bylo by chybou nevidět potenciál, který je v teorii racionální volby přítomen a který by bylo možno při budování sociologické teorie náboženství využít. Nemusíme samozřejmě souhlasit s důrazem na racionalitu rozhodování, ale můžeme souhlasit se snahou budovat teorii náboženství na vědeckých (tedy i ne-metafyzických, ne-teologických či ne-náboženských) základech. Druhým pozitivem je snaha budovat deduktivní a logicky jasně strukturovanou a přehlednou teorii, která otevírá prostor pro nová empirická šetření. Třetím pozitivem je skutečnost, že teorie racionální volby navazuje (samozřejmě i kriticky) a rozvíjí klasické sociologické koncepty a př́stupy (od Webera k např́iklad Parsonsovi). Dalším pozitivem je to, že ačkoliv jde o sociologickou teorii s návazností na existující sociologický (a religionistický) diskurs, snaží se teorie racionální volby hledat inspiraci i v jiných společenskovědních oborech a z nich čerpat.

Podíváme-li se ještě na jeden výrazný rozdíl mezi dvěma verzemi teorie racionální volby v oblasti sociologie náboženství, uvidíme mezi nimi posun, který nám umožní hledat možné spojovací články mezi novější verzí teorie racionální volby a některými současnými snahami o hledání nové vědecké teorie náboženství. Zatímco v A Theory of Religion je pro vymezení náboženství klíčové pojetí „kompenzátorư“ jako př́slibu odměn, kterých lze dosáhnout podle určitých návodů, jejichž účinnost však nelze jednoznačně zhodnotit (kompenzátor nabízí víru, že uspokojení bude dosaženo ve vzdálené budoucnosti nebo za nějakých odlišných podmínek, které nemohou být okamžitě nastoleny, takže nemůže být ověřena jejich působnost), a náboženství je tedy definováno jako „systém obecných kompenzátorů založených na nadpřirozených předpokladech, přičemž nadpřirozené se chápe jako něco, co odkazuje na síly, které jsou mimo přírodu a které silám prŕrody napomáhají nebo je přeměňují či ignorují“ (Stark a Bainbridge 1987: 36-39), pak v Acts of Faith je architektura teorie odlišná. Začíná tvrzením (propozicí), podle kterého se lidé snaží dělat racionální volby a to $\mathrm{v}$ rámci informací, které mají $\mathrm{k}$ dispozici, v rámci dostupných možností a ovlivněni svými preferencemi a zálibami. Lidé jsou pak chápáni jako vědomé bytosti, které mají pamět’ a inteligenci a jsou schopni formulovat vysvětlení o tom, jak je možné dosáhnout odměn a vyhnout se ztrátám. Existují přitom „mimosvětské odměny“ (otherworldly rewards), které lze získat pouze v neempirickém (často posmrtném) kontextu. Náboženství se pak skládá z velmi obecných vysvětlení existence, včetně termínů směny s bohem či bohy (Stark a Finke 2000: 85-92). Druhá verze teorie racionální volby tedy větší důraz klade na kognitivní, emocionální a expresivní stránku člověka, jeho jednání, včetně náboženství, což je posun, který odráží (byt' jen mírně) nový silný impuls, který v druhé polovině 20. století postupně sílí, až $\mathrm{k}$ závěru století získá na síle uragánu. Ten pak vtrhnul do všech oblastí společenských a humanitních věd, byt's různou intenzitou a v různé podobě. 


\section{Mimosociologické impulzy}

Obrat ke kognitivním přístupům, jejichž základy byly samozřejmě položeny dř́ve, probíhá přibližně od 60 . let minulého století, přičemž za symbolický začátek obratu můžeme považovat věhlasnou přednášku Noama Chomského o teorii jazyka na Massachusettském technologickém institutu (MIT) v roce 1956. Od té doby bylo ke kognitivním př́istupům napsáno obrovské a nepřehledné množství odborných textů z nejrůznějších oborů od lingvistiky přes neurovědu až po sociální a kulturní antropologii a tento obrat později sám Chomsky charakterizoval jako změnu perspektivy „od studia chování a jeho produkti̊ (textů atd.) $\mathrm{k}$ vnitřním procesům, které se skrývají za lidským konáním, a k jeho původu v biologickém vybavení člověka“" (Chomsky 1998: 17).

Jestliže se sociologie (a jiné sociální vědy) snažily záměrně vyhnout otázce po jiných než sociálních a kulturních příčinách lidského chování a jednání, pak s vývojem, ke kterému došlo v biologii, neurologii a psychologii (následně pak i v dalších vědních oborech), je toto odmítání zproblematizováno a ukazuje na určitá omezení tradicionalisticky koncipované sociologie. Ukažme si nyní několik význačných impulsů, které by sociologie (alespoň podle našeho názoru) neměla ignorovat, ale prrímo začlenit do základů své perspektivy (a tím tuto perspektivu změnit).

Sociobiologie jako ,systematické studium biologického základu všech forem sociálního chování všech druhů organismů včetně člověka“ (Wilson 1993: 24-25) přinesla perspektivu, kterou oživila naturalistický a darwinistický pohled na člověka. Zaměřila se na studium sociálních živočichů, především na tři skupiny (vrcholy sociální evoluce u živočichů): a) korálnatce, mechovky a další bezobratlí vytvářející kolonie, b) sociální hmyz (tedy mravence, vosy, včely a termity), c) sociální ryby, ptáky a savce; a došla k závěru, že člověka spojují s některými jinými živočichy (především se savci, respektive s velkými lidoopy) některé znaky, formy chování a způsoby sociální organizace. Např́iklad to, že naše malé či intimní sociální skupiny zahrnují řádově od deseti do sta dospělých jedinců; samci jsou větší než samice; mlád'ata formuje dlouhé období sociálního tréninku, nejprve v podobě nejužšího sepětí s matkou, pak stoupající měrou s jinými dětmi téhož věku a pohlaví; sociální hra je silně rozvinutá aktivita, která zahrnuje nácvik sociálních rolí, předstíranou agresi, sexuální praktiky a průzkum okolí (tamtéž).

Podle Wilsona tzv. nový naturalismus nastoluje dvě velká dilemata. Prvním je skutečnost, že neexistuje žádné určité místo, ke kterému bychom měli směřovat, a že cíl žádného biologického druhu (tedy ani člověka) nesahá za imperativy vytvořené jeho genetickou historií. Součástí tohoto dilematu je tvrzení, že lidská mysl je zkonstruována tak, že volí pouze na základě biologického mechanismu. „Jestliže se mozek vyvíjel na základě přírodního výběru, musely i schopnosti zvláštního estetického úsudku a náboženské víry vzniknout stejným mechanickým procesem. Jsou bud' přímou adaptací na minulá prostředí, v nichž se předcházející lidská populace vyvíjela, nebo je u většiny organismů vyvolána sekundárně, hlubšími, méně viditelnými aktivitami, které kdysi byly výhodné v tomto př́isnějším biologickém smyslu“ (Wilson 1993: 13). Mozek tedy podporuje přežití a násobení genů, které jej rrídí; lidská mysl je nástrojem přežití. „Lidské emocionální reakce jsou v zásadě naprogramovány přirozeným výběrem po tisíce generací. Před vědou je úkol změřit těsnost bariér způsobených tímto naprogramováním, nalézt jejich zdroje $\mathrm{v}$ mozku a dešifrovat jejich význam pomocí 
rekonstrukce evoluční historie mysli“ (Wilson 1993: 16). Druhé dilema pak spočívá v hledání odpovědi na otázku, kterým z těchto „,cenzorů“ je nutno se podřídit a které je vhodnější spíše omezit nebo potlačit (Wilson 1993: 16), tedy zda je možné využívat, rozvíjet či omezovat ,lidskou přirozenost“.

Ukažme si na dvou př́padech Wilsonovu aplikaci sociobiologické perspektivy na téma náboženství, a to na základě tvrzení, že i náboženské chování může být důsledkem evoluce na základě přírodního výběru. První příklad dokládá selektivní výhodu, která vyplývá z členství v náboženské skupině, respektive skupině, která je náboženstvím silně integrována. Náboženská skupina spojená vroucí vírou a jasným cílem má podle Wilsona dědičnou selektivní výhodu, nebot' geny členů této skupiny mají větší šanci na přežití (přenesení na další generaci) v důsledku vnitroskupinového altruismu, tedy skutečnosti, že jednotlivci, členové skupiny jsou ochotni i obětovat svůj vlastní život pro přežití skupiny (Wilson 1999: 289). Druhým př́kladem je téměř univerzální výskyt ideje (a s ní spojeného chování) smíření a obětování ve všech náboženstvích. Ve své podstatě jde o akty podřizení se dominantní bytosti, což je jedním z typů hierarchie, která je obecným rysem organizovaných společenstev savců. Existuje tedy „sémiologická podobnost mezi podřízeným chováním zviřat na jedné straně a lidskými projevy nejhlubší úcty vůči náboženským a občanským autoritám na straně druhé [...]; nejsložitější rituály projevů úcty jsou adresovány bohům, superdominantním, byt' neviditelným členům lidské skupiny“ (Wilson 1999: 290-291). V tomto kontextu zní Wilsonův závěr jasně: „Nespočetné studie o různých druzích zviřat, jejichž instinktivní chování není zatemněno kulturním vývojem, ukázaly, že členství v dominantních uspořádáních je odměněno úspěchem, pokud jde o přežití a celoživotní reprodukci. To platí nejen pro dominantní, ale i podřízené jedince. Členství v té či oné skupině poskytuje zvířeti větší ochranu proti nepřátelům a lepší př́stup $\mathrm{k}$ jídlu, úkrytu a partnerům než samotářská existence. Navíc ani podřizené postavení ve skupině není permanentní. Dominantní jedinci slábnou a umírají, a tak další z podřizených postoupí v pořadí a přivlastní si více. Zjištění, že moderním lidem se podařilo vymazat staré genetické programy savců a vymyslet jiné způsoby rozdílení moci, by bylo překvapivé"“ (Wilson 1999: 291).

Perspektiva sociobiologie v mnoha ohledech umožňuje doplnění teorie náboženství, respektive vynucuje si reformulaci některých základních principů, na nichž je jakákoliv dosavadní sociologická teorie náboženství založena, a v důsledku toho i celkovou rekonstrukci celé stavby teorie náboženství. V případě teorie racionální volby např́klad silně zpochybňuje racionalitu volby, tedy základ, na kterém je teorie racionální volby postavena. A v případě teoretického rámce sekularizace dochází k paradoxnímu (a vlastně sekularistickému) závěru: „tradiční náboženské víry se rozpadly ani ne tak pokořujícím vyvrácením svých mytologií jako spíše rostoucím vědomím, že víry jsou ve skutečnosti mechanismy umožňující přežití“ (Wilson 1993:14).

Evoluční a kognitivni psychologie začleňuje člověka (podobně jako sociobiologie) mezi další živočichy a snaží se vysvětlit některé prvky lidského myšlení a chování z evolučního hlediska. Představuje základ kognitivního studia náboženství a s dalšími kognitivně zaměřenými př́stupy se prolíná. Společný základ mají např́klad v premise, že lidský mozek funguje stejně dnes jako v archaické minulosti. Vzhledem ke svým kořenům v darwinismu a konceptu evoluce je pro evoluční psychologii klíčovým pojmem adaptace, respektive koncept 
„prostředí evolučních adaptací“ (environment of evolutionary adaptedness - EEA). EEA je soubor selekčních tlaků, které působily během lidské evoluce, přičemž jejich jádro časově leží v pleistocénu (přibližně 2,5 miliónu let), tedy období ještě před dvěma skutečně revolučními zlomy - vznikem zemědělství (před 10000 lety) a kulturní „,revolucí“ (přibližně před 40000 lety). V této době se vytvořily základní mechanismy adaptace, ale také myšlení a chování, které jsou dodnes součástí lidského EEA. Avšak masivní kulturní změny, které se odehrály v posledních 10000 letech, se součástí lidského EEA nestaly, protože proběhly př́liš rychle a lidský mozek (a tedy i chování) se na ně nemohly adaptovat. Jinými slovy: ,adaptace, jimiž dnes disponujeme, byly vybrány pro naše minulé prostředí evolučních adaptací (EEA) [...] a nejsou již použitelné pro moderní svět“, „svět, na který jsme adaptováni, již neexistuje, ale v důsledku evolučního zpoždění pokračujeme v takovém chování, jako by stále existoval“ - ,jsme lidmi doby kamenné jedoucími v dálničním pruhu“ (Barrett, Dunbar a Lycett 2007: 40).

Nicméně pro pochopení lidského chování a jednání je dobré si uvědomit podmínky, které toto chování umožňují - tedy především lidský mozek a rozvinutá kultura. Z evolučního hlediska je rozvoj lidského mozku bezprostředně a úzce propojen se sociální stránkou člověka. Ukazuje to tzv. hypotéza sociálního mozku, která se snaží vysvětlit existenci relativně velkého mozku u člověka a ostatních primátů. Primáti mají totiž v poměru ke své tělesné velikosti velké mozky a lidé mají neúměrně velké mozky i mezi primáty. $\mathrm{V}$ rámci struktury mozku však jde především o velikost neokortexu (vývojově nejmladší části centrální nervové soustavy), přičemž impulsem pro jeho růst a rozvoj byla snaha navazovat cenné sociální vztahy a využívat je k vlastnímu prospěchu: „stále manipulativnější strategie užívané některými jedinci vytvářely u ostatních selekční tlak na vývoj stejně prohnaných protistrategií, jež by umožňovaly podvodům a manipulaci čelit, což zase vedlo $\mathrm{k}$ výběru jedinců $\mathrm{s}$ ještě větší schopností přelstít své protivníky“ (Barrett, Dunbar a Lycett 2007: 194). Výzkumy v této oblasti prokázaly, že u primátů (včetně lidí) velikost neokortextu koreluje s velikostí sociální skupiny, s velikostí klanů navzájem se čistících jedinců, s rafinovaností sociálních strategií, jež samci používají při soutěžení o partnery, s četností společenských her a četností taktického klamání (Barrett, Dunbar a Lycett 2007: 194-195). Díky tomuto velkému a strukturovanému mozku došlo u člověka k rozvoji jak primárního vědomí (to však mají i zvířata), tak především vědomí vyššího řádu. K tomuto vědomí vyššího řádu patří

biologická individualita, schopnost svébytného konání ve vzpomenuté přítomnosti a sociálně a jazykově definované já. Jsme si vědomi vlastního vědomí, máme jasné povědomí o vlastní minulosti a můžeme konstruovat scénáře budoucích událostí. Ovládáme skutečný jazyk, poněvadž máme syntaktické schopnosti jako doplněk svých schopností fonetických a sémantických. Rozvoj slovní zásoby nám umožňuje použít verbální znaky a symboly a odpoutat se tak od vzpomenuté př́tomnosti. Toto odpoutání je možné díky zaměření pozornosti na události mimo vzpomenutou prítomnost. (Edelman 2010: 87-88; více Edelman 1989, 1987)

Člověk má tedy vysoce rozvinuté metareprezentační schopnosti, díky nimž může vedle primárních reprezentací (pravdivé domněnky o světě) vytvářet také sekundární reprezentace (domněnky o svých domněnkách), které nemusejí př́mo odpovídat skutečnosti a nemusejí tedy odrážet realitu (Barrett, Dunbar a Lycett 2007: 390-391). Vedle toho může 
vytvářet domněnku o obsahu mysli jiné osoby, respektive člověk chápe, že jiní lidé mají mentální stavy (myšlenky, přání, domněnky) a že tyto mentální stavy řídí jejich chování (Barrett, Dunbar a Lycett 2007: 384). K těmto specifickým vlastnostem člověka je nutno (kromě jiného) přičíst také schopnost fantazie a vyprávění př́iběhů (včetně velmi rozšířených a významných ,př́íběhů o prapůvodu“, tedy i náboženských mytologií a kosmogonií).

Pro sociologii (a její teorii) je výzva ze strany psychologie možná nepř́íjemná, avšak zohlednění evoluční psychologie a psychologie vývojové (která zdůrazňuje význam studia ontogeneze a především význam studia kognitivního vývoje v dětství) se zdá být pro současnou sociologii nezbytností. Přidáme-li k tomu apel kognitivní psychologie, tedy studium toho, jak lidé vnímají svět kolem sebe, jak nakládají s těmito informacemi, jak se učí, jak si pamatují, jak strukturují myšlení, jak předávají informace apod. (srv. např́klad Eysenck a Keane 2008, Sternberg 2009), pak, ačkoliv se sociologie nemusí bezprostředně těmito otázkami zabývat a realizovat takto zaměřený výzkum, musí si být vědoma širších souvislostí a podmíněností svých témat. Pro sociology jsou podle našeho názoru (s ohledem na cíl tohoto textu) důležitá následující shrnutí: „Pravidla, která řídí lidské chování, jsou relativně jednoduchá a - co je podstatnější - univerzální. Komplexnost lidského chování nevzniká z těchto pravidel, ale ze široké škály demografických, ekologických a sociálních prostředí, ve kterých se jednotliví lidé snaží tato pravidla uplatňovat.“” „Tato komplexnost vzniká kvůli dvěma rysům, které charakterizují všechny rozvinuté biologické systémy, a to díky obrovskému množství kontextuálních faktorů, které mají vliv na náklady a zisky určující rozhodnutí jedince, a časovému a energetickému omezení absolutní svobody volby.“ Navíc lidé mají oproti jiným zvířatům nejrozvinutější fenotypovou flexibilitu (jejich fenotyp může proměňovat své vlastnosti a znaky), k čemuž mimo jiné přispívá kultura. Výraznou specifičností člověka je totiž také kulturní přenos pravidel chování a ,skutečně převratná změna je způsobena faktem, že sociální přenos (mechanismus, který podpírá kulturu) otevírá možnost, že chování samo je obsaženo v negenetickém vývoji fitness [zdatnosti - pozn. D. L.]. Jinými slovy, fakt, že kultura může (ale nemusi) mít své vlastní kritérium pro fitness (memická fitness) [zdatnost, která je vytvářena a reprodukována prostřednictvím memů - pozn. D. L.] vznáší možnost, že určité lidské chování může představovat memickou maximalizaci genového fitness“ (Barrett, Dunbar a Lycett 2007: 484).

Pro sociologii se tedy v tomto ohledu otevírá možnost podržet si svoji specifičnost a studovat sociální a kulturní kontexty chování, současně se však může zvýšit její schopnost porozumět tomuto chování. Navíc by mohlo dojít k nesmyslnému rozpadu sociálního světa na část individuální, která je vyhrazena psychologickému studiu, a část kolektivní, která je doménou sociologické perspektivy. Kognitivní studium náboženství představuje syntézu a rozšíření kognitivních přístupů a jejich aplikaci na jednu část kultury - náboženství. Záměrně zde zdůrazňujeme, že náboženství je částí širšího celku, kterým je kultura, byt' se jedná o část velmi specifickou, a v určitých ohledech mimořádně důležitou. Pokud totiž chápeme náboženství jako součást kultury, pak můžeme k náboženství přistupovat stejným způsobem jako k jakýmkoli jiným částem (lidské) kultury a náboženství jim tedy není nijak nadřazeno.

Kognitivní studium náboženství (cognitive science of religion) v mnoha ohledech navazuje na předchozí vývoj religionistiky a kulturní antropologie, avšak jako výrazná „škola“ či směr (zde je možné oprávněně použít termín ,paradigma“) se zformovala na začátku 
tohoto století a za počátek je možné považovat publikování tří děl: Religion Explained: The Evolutionary Origins of Religious Thought (Boyer 2001), In Gods We Trust: The Evolutionary Landscape of Religion (Atran 2002) a Why Would Anyone Believe in God? (Barrett 2004). Jakkoliv se tyto knihy od sebe liší, mají společná východiska, která jsou založena na perspektivě evoluční psychologie (srv. Downes 2011: 1-2). Nicméně perspektiva kognitivního studia náboženství se formovala již od osmdesátých let (kromě zmíněných autorů také např́íklad v dílech Dana Sperbera) a vyústila v první podoby kognitivní teorie náboženství v dílech Rethinking Religion: Connecting Cognition and Culture (Lawson a McCauley 1990), Faces in the Clouds: A New Theory of Religion (Gurthrie 1993) a The Naturalness of Religious Idea: A Cognitive Theory of Religion (Boyer 1994). Tato základní podoba teorie je pak následně rozvíjena např́klad v dílech Arguments and Icons: Divergent Modes of Religiosity (Whitehouse 2000), Modes of Religiosity: A Cognitive Theory of Religious Transmission (Whitehouse 2004), How Religion Works: Toward a New Cognitive Science of Religion (Pyysiäinen 2003), která představují pokus o propojení antropologie a psychologie. S rozvojem neuorologie a technik snímkování činnosti mozku dochází v současné době k rozmachu experimentálního výzkumu (srv. naprríklad Newberg, D‘Aquili a Rause 2001; McNamara 2006, 2009).

S kognitivním studiem náboženství se vrací dávná otázka po původu náboženství (a po způsobech jeho předávání), přičemž vzhledem k velkému vlivu psychologie a teorie chování a jednání je základním východiskem metodologický individualismus. Díky tomu je v základech kognitivního přístupu zřejmý ahistorismus, protože pokud se ptáme po původu náboženství u jednotlivců, musíme vyjít z nějakého obecně lidského základu. Tím je ,intuitivní ontologie“", tedy všem lidem společná (geneticky a evolučně podmíněná) očekávání, že se určité entity budou chovat určitým způsobem. Již malé děti mají rozdílná očekávání vůči chování lidí, rostlin, zvířat a materiálních neživých předmětů. Tato intuitivní ontologie se pak skládá z intuitivní fyziky, intuitivní psychologie a intuitivní biologie, přičemž každá entita $\mathrm{z}$ těchto domén je spojena s určitými vlastnostmi. Pro vznik náboženství je pak klíčové narušení těchto očekávání, respektive situace, kdy dochází k míchání vlastností z jednotlivých domén. Např́klad z intuitivní fyziky a psychologie vyplývá, že kámen padá ze skály dolů a nemluví. V situaci, kdy se objeví kámen (nebo jeho představa), který mluví a leze po skále nahoru, jsou intuitivní očekávání narušena a je i narušena intuitivní ontologie (v důsledku míchání vlastností z jednotlivých domén). Vzniká tzv. kontraintuitivní idea či představa - mluvící strom, tělo procházející zdí, nesmrtelná osoba nebo osoba, která nemá tělo, apod. Tyto představy jsou pak základem náboženství. Tento přístup ústí v tvrzení, že náboženství není žádnou specifickou doménou, ale že je součástí obecné lidské schopnosti imaginace a vznik náboženství souvisí s běžným fungováním lidského mozku a mysli. Z tohoto pohledu je náboženství ,přirozené“ (i když pracuje s předpokladem „,nadpřirozena“).

Základní rámec kognitivního studia náboženství nachází uplatnění v různých dílčích tematických oblastech výzkumu náboženství. Zde se s ohledem na rozsah textu a jeho zaměření alespoň krátce zmiňme o problematice šíření náboženství. Jedním z nich je koncept modů náboženskosti Harveye Whitehouse, který vychází ze dvou triviálních (ale o to více efektivních) předpokladů: aby mohly náboženské představy a rituály přetrvávat a mohly být 
předávány, 1) musí se utvořit do takové podoby, kterou si lidé mohou zapamatovat, a 2) lidé musí být motivováni tyto představy a rituály předávat. Lze rozlišit doktrinální (doctrinal) a obrazivý (imagistic) modus náboženskosti. Doktrinální modus náboženskosti je takový, jehož rituální stránka má podobu vysoce rutinizované činnosti, což usnadňuje udržování propracovaných a koncepčně složitých náboženských nauk v sémantické paměti (sémantická pamět' je součástí dlouhodobé explicitní paměti, tedy takové paměti, která se zabývá věcmi, které víme vědomě, uchovává informace po dlouhou dobu a obsahuje všeobecné znalosti o světě, přičemž si většinou nejsme schopni vzpomenout, jak a kdy jsme tyto informace získali). Při výkonu většiny rituálů dochází současně k aktivizaci implicitní paměti (ta se zabývá věcmi, které známe, ale nejsme si přitom vědomi, že je známe - např́klad různými neuvědomovanými dovednostmi). Obrazivý modus náboženskosti je spojen s činnostmi, které se nevyskytují prŕiliš často a u aktérů vyvolávají velké vzrušení. Zahrnuje nejrůznější stavy extáze, zkušenost kolektivní posedlosti a stavy změněného vědomí, včetně násilných či trauma vyvolávajících rituálů. Whitehouse spojuje tyto mody s odlišnými hypotézami. Zatímco u doktrinálního modu náboženskosti 1) časté opakování aktivuje k osvojení náboženského učení sémantickou pamět', 2) sémantická pamět' užívaná k osvojování náboženského učení a přítomnost náboženských vůdců se navzájem podporují, 3) přítomnost náboženských vůdců s sebou přináší potřebu kontroly ortodoxie, 4) časté opakování vede k využívání implicitní paměti během provádění náboženských rituálů, 5) užití implicitní paměti během výkonu náboženských rituálů zvyšuje šance na přetrvání autoritativního učení uloženého v sémantické paměti, 6) potřeba kontroly ortodoxie podporuje snahy o náboženskou centralizaci, 7) užívání sémantické paměti k osvojování náboženského učení vede ke vzniku anonymních náboženských společenství; u obrazivého modu náboženskosti 1) zřídkavé opakování a vysoká míra vzrušení aktivují epizodickou pamět', 2) aktivizace epizodické paměti uvádí v činnost spontánní exegetickou reflexi, která vede ke vzniku expertních exegetických struktur uložených v sémantické paměti, 3) spontánní exegetická reflexe vede k různorodosti náboženských reprezentací, 4) spontánní exegetická reflexe a různorodost reprezentací zabraňuje ustavení dynamického vůdcovství, 5) absence dynamického vůdcovství, nedostatek centralizace a nepř́tomnost ortodoxie se navzájem podporují, 6) vysoká míra vzrušení podporuje intenzivní soudržnost skupiny, 7) intenzivní soudržnost a epizodická pamět’ rozvíjejí vznik lokálních a exkluzivních komunit a 8) lokalizované/exkluzivní komunity a nepř́tomnost dynamického vůdcovství zpomalují šíření náboženské tradice (Whitehouse 2009: 211-224; podrobněji např́íklad Whitehouse 2000, 2004).

Whitehousův model však nelze chápat jako striktní a jednoznačné vyjádření zákonitých pravidel individuálního chování, ale spíše jako vyjádření tendencí uvnitř náboženských tradic. Pro sociologii náboženství může být také inspirativní proto, že více než jiné kognitivní přistupy zohledňuje sociální rovinu. Na jedné straně se jeho model zaměřuje na kognitivní rovinu lidského náboženského chování (jak jsou náboženské aktivity zpracovávány psychicky), na straně druhé zohledňuje význam sociopolitické roviny tohoto chování (sociální a politické organizace na úrovni skupiny a populace). Slovy Whitehouse: „Seskupování sociopolitických rysů náboženství bylo rozpoznáno již relativně dávno, novinkou, kterou přináší teorie ,dvou modů náboženskosti‘, však je, že tyto rysy zapojuje do jednoho modelu a následně toto seskupování vysvětluje $\mathrm{z}$ hlediska působení souboru kognitivních 
a psychologických“ (Whitehouse 2009: 224). Zde se přímo otevírá prostor pro spolupráci sociologie, antropologie, psychologie.

Kognitivní archeologie $\mathrm{v}$ některých momentech přichází $\mathrm{k}$ podobným závěrům, které navíc mají výraznou sociologickou relevanci, nebot' ukazují, že centrálním bodem náboženství je hierarchie a moc. Klasickým př́kladem jsou práce Davida Lewis-Williamse, archeologa, který si klade otázky, které na první pohled nemají se sociologií př́liš společného: Proč lidé v mladém paleolitu vytvořili jeskynní obrazy? Jaký je původ obrazivého umění mladého paleolitu? Proč lidé vytvořili umělecká díla $\mathrm{v}$ temných a neprrístupných podzemních prostorách (jako např́klad ve francouzských jeskynních komplexech Enlène a Les trois Frères nebo Niaux a Réseau Clastres či v proslulé španělské Altamiře)? Jeho odpověd' je však pro sociologii zajímavá a př́nosná: tyto kresby a malby měly náboženský charakter, byly vytvořeny ve stavech změněného vědomí, vytvořily je osoby, které měly schopnosti těchto stavů dosáhnout, a byly součástí i nástrojem sociální diverzifikace a hierarchie.

Dủležité pro pochopení specifičnosti a výjimečnosti tohoto období je reflexe změny v myšlení a chování lidí, ke které došlo mezi mladým a středním paleolitem a která je nápadně vidět na rozdílném způsobu života (a tedy i myšlení) mezi Homo neanderthalensis a Homo sapiens (komunity těchto dvou typů lidí žily vedle sebe celých 10000 let). Rozdíly byly obrovské a výsledkem bylo vyhynutí neandrtálců během krátkého období jednoho tisíce let. Př́slušníci společenství Homo sapiens například uměli uchovávat potravu na zimu, což umožnilo přežití více dětí. Avšak nejvýraznější rozdíl byl v kognitivních schopnostech. Tito lidé již totiž měli moderní jazyk, což znamená, že vydávali zvuky, které měly význam, byli schopni vytvářet složité gramatické konstrukce, mluvit o minulosti i budoucnosti, sdělovat abstraktní myšlenky a vyjadřovat se ve srozumitelných větách (Lewis-Williams 2007: 113). Tato schopnost, respektive rozvoj jazyka, těsně souvisí se složitostí sociálních vztahů - čím jsou sociální vztahy složitější, tím je komplikovanější jazyk a komunikační systémy dané společnosti (Lewis-Williams 2007: 114). Nejde však pouze o jazyk, ale o celý způsob myšlení a orientace ve světě. Zde kromě sociálních vztahů hraje významnou úlohu druhý faktor, kterým je mozek, přičemž platí, že i neurologická struktura mozku úzce souvisí se složitostí sociálních vztahů - díky složitosti sociálních vztahů (např́ílad díky nutnosti rozsáhlé kooperace při lovu, což byla aktivita, kterou neandrtálci neznali) došlo k rozvoji mozku a jeho neurologické struktury.

Lewis-Williams pak tuto část svých úvah uzavírá s tím, že neandrtálci měli v mnoha významných ohledech jiný typ vědomí než lidé mladého paleolitu, a proto např́klad nemohli malovat obrazy ani pohřbívat své mrtvé s množstvím ozdobných předmětů. Neurologická struktura jejich mozků a typ vědomí, který vytvářela, neandrtálcům neumožňovaly: a) rozvíjet svoji obrazotvornost a vytvářet si představy (mentální obrazy) odvozené od řady různých stavů vědomí, b) s těmito představami nakládat a sdílet je s ostatními členy svého společenství, c) pomocí socializace těchto představ si vymýšlet „alternativní realitu“, ,paralelní stav bytí“ nebo „svět duchů natolik pamětihodný a s takovým emočním nábojem, že se stával konkrétním a žil svým vlastním životem“, d) rozpoznat spojitost mezi mentálními obrazy a obrazy dvojrozměrnými a trojrozměrnými, e) rozpoznat dvojrozměrná a trojrozměrná zobrazení trojrozměrných věcí v hmotném světě, f) žít v souladu se sociálními rozdíly, podloženými různými stupni těchto schopností a rozdílným prrístupem k typům mentálních obrazů 
(Lewis-Williams 2007: 118-119). Jinak řečeno: „V plném smyslu moderní lidské vědomí na rozdíl od neandrtálského zahrnuje schopnost $\mathrm{v}$ různých stavech si vytvářet představy o světě, pamatovat si je a mluvit o nich s jinými lidmi v obecně přijatém rámci (jinými slovy je socializovat) a také je zobrazovat.“ Díky tomu měli tito lidé také schopnost imaginace, schopnost používat imaginaci v různých sociálních souvislostech, schopnost vytvářet, ,ŕŕši duchư“ a připravovat mrtvé na vstup do ní (Lewis-Williams 2007: 119). Jinými slovy: neandrtálci díky jednoduchosti sociálního života a s ní propojené jednoduchosti neurologické struktury mozku nemohli rozvinout tak složitý imaginativní systém, jako je náboženství. To je pak výsadou „moderního člověka“ Homo sapiens, pro jehož chování je podle některých autorů typické: a) abstraktní myšlení, schopnost jednat na základě časově a prostorově omezených pojmů, b) schopnost plánovat, vytvářet strategie založené na minulé zkušenosti a uskutečňovat je ve skupinovém kontextu, c) schopnost behaviorální, ekonomické a technické inovace, d) symbolické chování, schopnost zobrazovat předměty, lidi a abstraktní pojmy pomocí předem dohodnutých zvukových a zrakových symbolů a zhmotňovat tyto symboly v kulturní praxi (Lewis-Williams 2007: 124).

Inspirativní výzva Lewise-Williamse a dalších podobně orientovaných autorů je zřejmá: pro adekvátní pochopení chování a jednání (a samozřejmě také myšlení) člověka (současného i paleolitického) je třeba studovat dva vzájemně propojené a související faktory: neurologickou strukturu a fungování lidského mozku a sociální strukturu a vztahy. Náboženství jako specifická podoba mentálních stavů a představ je výsledkem fungování našeho nervového systému a je neodmyslitelnou součástí lidského bytí. Tyto (a další stavy) jsou „zapojeny“ v mozku. Náboženské zážitky, prožitky a představy jsou jistou formou „změněného stavu vědomí“ a jsou ,psychobiologickou schopností" lidského druhu, a jsou tedy univerzální vyskytují se ve všech lidských pospolitostech a lidských myslích. Vyskytují se však jako univerzální formy či struktury, které v různých společenských a kulturních (ale také krajinně-regionálních) kontextech nabývají různého obsahu. Lewis-Williams opakovaně zdůrazňuje, že se nejedná o nějaký striktní determinismus: „Ve změněných stavech vědomí lidská nervová soustava generuje geometrické vizuální vjemy. Lidé ale nejsou něco jako kopírky neschopné jakýchkoliv citů. Opět zdůrazňujeme, že na neuropsychologickém modelu není nic deterministického. Je prostě potenciálním zdrojem duševních představ, fungujícím způsobem, který odhaluje progresi těchto představ. Lidé si vybírají vjemy ze široké nabídky, standardizují je způsobem podmíněným jejich kulturním prostředím“ (Lewis-Williams a Pearce 2008: 305).

Pro sociology bude jistě zajímavé, že ačkoliv jsou tyto vjemy (díky svému původu v neurologické struktư̌e mozku) potenciálně př́istupné každému člověku, ne každý jich může dosáhnout a také ne každý s nimi umí pracovat. Již od počátku lidského společenství existovali jedinci, kteří díky (skutečným nebo proklamovaným) schopnostem dosažení a zpracování těchto stavů a vjemů získali význačnější postavení v sociálních vztazích a ve struktuře daného společenství. Proto byly např́iklad některé kresby v jeskynních či megalitických hrobkách umístěny na přistupných místech (tj. byly určené širokému společenství) a jiné na velmi těžko dostupných místech $\mathrm{v}$ malých a naprosto temných prostorách, jejichž dosažení vyžadovalo nejen velkou námahu a zručnost, ale také odvahu a jasnou motivaci. Tato místa, která měla naprosto specifickou atmosféru (kterou si nedovede sociolog ve své akademické pracovně představit, pokud nezažil např́iklad více jak hodinové putování v temných 
jeskynních komplexech, v nichž se musí plazit či brodit hluboké vodní nádrže) a v nichž bylo ,jednodušší“ dosáhnout změněných stavů vědomí a náboženských zážitků, byla určena jen pro některé, a tito jedinci pak (díky svým mimořádným schopnostem) získávali v daném společenství mimořádnou moc. Náboženství tedy bylo od svého počátku neoddělitelně spojeno se společenskými vztahy a hierarchií. A nejen náboženství: „Lidskou mysl utvářel mozek a změny vztahů ve společnosti““ (Lewis-Williams 2007: 88).

Druhou sociologicky významnou stránkou tohoto př́stupu je skutečnost, že existence a chápání změněných stavů vědomí musí být vždy sociálně vyjednány. Slovy LewiseWilliamse a Davida Pearceho: musí existovat nejen „smlouva s vědomím“ na úrovni jedince, ale také ,společenská smlouva“ na úrovni celého společenství, které uspořádávají (dávají rád) celému spektru vědomí (od bdělého stavu až po introvertní konec spektra v podobě halucinací - „každé lidské společenství se musí vyrovnat s posuny v lidském vědomí. Každé si musí rozdělit spektrum vědomí a přičíst různé hodnoty jeho složkám - jinými slovy, dohodnout se na smyslu rozmanitých duševních stavů, které prožívá každý z nás. [...] Změněné vědomí proto vždy zaujímá místo v sociální a politické matici. Změněné stavy je nutné vždy zkoumat v sociálních souvislostech“" [Lewis-Williams a David Pearce 2008: 73]). ${ }^{6}$

Zde je zřejmé, že bez sociologie nelze adekvátně zkoumat jakékoliv náboženství, a to dokonce ani náboženství neolitické. Na první pohled psychologicky zaměřený neuropsychologický model náboženství, který jádro (původ) náboženství klade do změněných stavů jedinců, ústí v požadavek propojit kognitivní přístup s přístupem sociologickým. Pokusme se tedy nyní naznačit hrubé rysy takového pojetí.

\section{Směrem k biokulturní teorii náboženství}

Kognitivní obrat ve studiu náboženství zahrnuje velkou řadu teoretických konceptů a empirických výzkumů od různě zaměřených autorů (dobrý vhled představuje např́íklad Light a Wilson 2004). Pro sociologii náboženství tento obrat znamená výzvu, se kterou by se měla kriticky vyrovnat, což však v žádném př́ipadě neznamená odvrhnutí dosavadních sociologických konceptů a poznatků. Právě naopak: jde o další rozpracování sociologické teorie (náboženství) a jejího (kritického) obohacení o poznatky jiných oborů. Platí přitom, že rovina „biologické - kulturní“ představuje jednu ze čtyř základních os sociologické perspektivy (Lužný 2010b: 345-346).

$6 \quad$ K pojetí Lewise-Williamse a Davida Pearceho blíže viz Wiebe (2009). Českému čtenáři je také př́istupna stat' Donalda Wiebeho, v níž tento autor nejen vysoce vyzdvihuje prŕístup Lewise-Williamse, ale také ostře kritizuje př́istup Pascala Boyera (Wiebe 2011).

7 Termín „biokulturní př́stup“ $k$ náboženství se dnes objevuje velmi často. Např́íklad Michael Winkelman a John R. Baker (2010) vysvětlují tento př́stup jako náhled, podle kterého je religiozita produktem jak našeho biologického ustrojení (makeup), tak naší socializace do specifické kultury. Tento náhled vychází z obecnějšího východiska, podle něhož jsou lidé biologické organismy, jejichž nejdůležitějším nástrojem adaptace ve světě je kultura. Biokulturní perspektiva se snaží vysvětlit dvě stránky jednoho problému, tedy proč lidé mají přirozené, biologicky založené sklony $\mathrm{k}$ religiozitě, a jak tyto sklony nacházejí své vyjádření na různých místech a v různých obdobích (Winkenlman a Baker 2010: 7). 
V následující části se pokusíme zformulovat návrh základních tezí sociologické teorie náboženství, byt' tak činíme s vědomím nedostatečnosti, která však může být korigována další kritickou diskusí (následující body jsou rozpracováním a rozšířením tezí, které byly představeny v Lužný 2011), a s vědomím, že jednotlivé teze nejsou samy o sobě často nijak originální. Jistou míru původnosti má (doufejme) návrh jako celek.

1. Základním objektem (předmětem, tématem) sociologie náboženství je člověk. Svojí povahou je tedy sociologie náboženství antropologickou disciplínou a také disciplínou antropocentrickou. Znamená to, že sociologie nemůže chápat jako relevantní př́ímé sociální aktéry jiné entity než člověka (např́klad Boha, bohy, zvířata, stavby, skály apod.). Existenci těchto entit však sociologie nemůže ignorovat, pokud byly nebo jsou součástí sociálního světa člověka. Stanou-li se součástí sociálního světa člověka, stávají se tyto entity sekundárními aktéry (či spíše „spouštěči jednání“, „,aktanty“), nebot’ člověk jedná určitým způsobem $\mathrm{s}$ ohledem na tyto entity a také jim přičítá určitý význam. Člověk je v tomto pojetí chápán $\mathrm{v}$ několika rovinách - jako individuální bytost, jako skupinová bytost, jako součást lidstva, a to ve všech časových rovinách - v minulosti, přítomnosti, budoucnosti.

2. Člověk je pro sociologii přístupný prostřednictvím svého chování, tedy širokého souboru aktů, které mají materiální podobu (napríklad pohyb, ale také slovní vyjádření určité myšlenky). Sociologie pak zkoumá celý komplex lidského chování a jednání (samozřejmě včetně jednání sociálního). Toto jednání může studovat jak na rovině individuální, tak na rovině kolektivní. Ve svém studiu se přitom primárně zaměřuje na institucionalizované podoby chování a jednání. Sociologie náboženství zkoumá tu část chování, které bud' sociologie sama (etická perspektiva) nebo samotní lidé, které studuje („věřící“ i „nevěřící), za náboženské označují (emická perspektiva). V prvním př́padě musí sociologie náboženství explicitně definovat „,náboženstvi““, což jí opravňuje pojímat určité formy chování za náboženské, pokud tyto odpovídají patřičné definici. Tento př́stup umožňuje sociologii identifikovat určité jevy za náboženské, a to i přesto, že tyto jevy nejsou samotnými věřícími anebo obecným povědomím za náboženské považovány. Základem tohoto přístupu je bud' vymezení náboženství nějakou substancí či charakteristickým znakem (posvátné věci, nadpřirozené síly, kontraintuitivní představy apod.), které jej odlišují od „ne-náboženství, nebo prostřednictvím vztahování se ke konečným otázkám lidského života (například smrt, zlo apod.) a postulováním možností tyto otázky definitivně vyřešit jak na úrovni jedince, tak celého lidstva (např́iklad spása, ráj, nirvána apod.). Druhý př́́pad se pak zaměřuje na proces a způsoby interpretací určitých jevů tohoto světa, které jsou z nějakého důvodu věřícími považovány za součást náboženství. V tomto príípadě je teoretiky za náboženství považováno to, co je za náboženství považováno věřícími - jedinci či skupinami.

3. Studium lidského (náboženského) chování zahrnuje studium a) fyzických úkonů (například rituálů, ale také preferovaného způsobu přípravy jídla a stravování či preferovaného způsobu sexu a množení apod.), b) idejí a hodnot, ze kterých toto chování vychází a které je legitimizují (např́klad náboženství jako model světa a model pro svět), c) způsobů, kterými se tyto ideje a hodnoty prezentují (mluvené slovo, texty, obrazy apod.) a předávají (včetně náboženské socializace a konverze), d) důsledky tohoto chování, respektive důsledky uplatňování idejí a hodnot (např́klad míra natality u jednotlivých náboženských skupin, souvislost náboženského přsesvědčení s politickými preferencemi, souvislost náboženské 
příslušnosti se sociální hierarchií, vytváření a uplatňování strategií šíření daného náboženství, ale také např́iklad užití náboženství při legitimizaci násilí apod.).

4. Porozumění lidskému (náboženskému) chování, včetně sociálního jednání, předpokládá porozumění i jeho předpokladi̊m. Tyto předpoklady jsou a) biologické a b) socio-kulturní. Člověk je tedy druh živočicha, který má s ostatními živočichy více či méně společného, ale také odlišného a specifického. Je to živočich, který ve svém boji o přežití musí překonávat svoji biologickou nedostatečnost, což činí rozvojem kultury. V efektivitě tohoto úsilí mu napomáhají některé procesy (jako například habitualizace) ústící ve vznik institucí. Znamená to, že velká část lidského světa je sociálně (a tedy kulturně) konstruována.

5. Biologické základy lidské kultury způsobují existenci „lidských univerzálií“, tedy prvků života člověka a jeho chování, které se vyskytují ve všech kulturách a ve všech obdobích lidské existence. Tato univerzália mají biologický základ, vždy jsou však sociokulturně rámována. Sociologie pak zkoumá především ono sociokulturní rámování těchto univerzálií. Vedle toho může zkoumat i příčiny a podoby neuniverzálních podob lidského chování a jednání, vždy však zohledňuje jejich sociokulturní rámování. Mezi lidská univerzália patří: rození, zajišt'ování potravy, př́íprava a konzumace jídla, vyměšování, vidění a slyšení, sex, výchova a péče o potomky, umírání, myšlení, vytváření představ, vytváření symbolů, komunikace, vytváření mocenských struktur a hierarchií, oblékání se, vytváření hodnot a způsobů orientace ve světě, kooperace, násilí, nemoci, psychické stavy a city. S ohledem na lidská univerzália platí, že lidé dělají stejné věci, ale dělají je různě (různými způsoby). Sociologii pak primárně zajímají způsoby sociokulturní realizace těchto univerzálií a sociologii náboženství zajímá náboženské rámování (způsoby náboženské interpretace) univerzálií.

6. Začlenění biologické stránky člověka do agendy sociologie a snaha o vysvětlení člověka (a jeho chování, včetně náboženského) jako syntézy biologického a kulturního vede k zohlednění evoluce. Evoluční perspektiva umožňuje nahlížet na určité formy chování jako na součást vzájemných reakcí mezi člověkem a jeho okolím, respektive vysvětlit určité chování jako součást širokého procesu adaptace. Přitom se toto jednání může chápat jako součást adaptace, jako samostatná adaptační strategie, nebo jako vedlejší produkt vývoje. Náboženství pak v této perspektivě může být nahlíženo jako součást širokého komplexu adaptačních strategií, které člověku (jedinci i lidské pospolitosti) pomáhají v přežití, ale také jako vedlejší produkt evoluce.

7. Chceme-li porozumět člověku (a jeho chování či jednání) jako biologicko-kulturní bytosti, je vhodné propojit sociologii vědění se sociologii tělesnosti. Nezbytností je zohlednit fungování lidského mozku a lidské mysli. Díky tomu totiž můžeme pochopit jak biologické a kognitivní předpoklady sociálního konstruování reality, tak i kognitivní předpoklady existence, vzniku a předávání náboženství (náboženských představ). Začlenění poznatků kognitivních věd (především kognitivní psychologie a kognitivní neurologie) umožňuje analýzu náboženství ve vztahu ke způsobům, jak funguje lidský mozek a lidská mysl - jak člověk vnímá svoje okolí, jak ze svého okolí získává informace, jak tyto informace kategorizuje, jak konstruuje představu uspořádanosti (řádu) světa (jako základu náboženských kosmologií), jaké informace se lépe předávají (spojitost se šířením náboženství a tématem konverze), jak fungují kognitivní mechanismy rozhodování (možnost využití při analýze náboženské konverze; zde je možné propojení s teorií racionální volby), jaké informace, představy a způsoby chování 
se lépe pamatují (souvislost s tématem tradice a kulturní a náboženské paměti) atd. Tato perspektiva umožňuje propojit analýzy toho, jak lidé vnímají svět (epistemologii), jak zacházejí s těmito informacemi, jak se na tomto základě chovají (behaviorismus), jak sociálně konstruují svět (konstruktivismus) i jaký význam přikládají svému chování a jednání (hermeneutika).

8. Začlenění biologických předpokladů kultury (a náboženství) do sociologického uvažování neznamená jednosměrný biologický determinismus, byt' předpokládá, že jisté formy chování jsou biologicky (geneticky) naprogramovány. Biologická zakotvenost kultury a lidského chování představuje spíše rámec, v němž se různými formami realizuje lidské chování, které však může být i v rozporu s biologickým a genetickým naprogramováním. Na druhou stranu je třeba zmínit, že i kultura člověka předprogramuje, a také že i kultura ovlivňuje evoluci. Kultura (a náboženství) má sice kořeny v evoluci a v adaptativním nastavení člověka (je adaptivní strategií nebo výsledkem jiné adaptivní strategie či strategií), ale je také relativně samostatná. Člověk díky kultuře (a tedy i náboženství) na jedné straně zvyšuje svoji schopnost adaptace (a schopnost přežít) a svoji zdatnost (fitness), ale také díky ní může jít proti dosavadní evoluci.

9. Náboženství zde chápeme jako součást kultury, avšak jistě ne jako synonymum. Jde o specifickou část, která může být a často je v rozporu s jinými částmi kultury. Síla a mimorrádný význam náboženství spočívá $\mathrm{v}$ jeho nomologické funkci (dává světu řád a smysl) a ve schopnosti vybudit silné a dlouhotrvající emoce. Proto sociologie náboženství musí do své výzkumné agendy zařadit také téma emoci (emocionality).

10. Reflektování sociokulturní roviny člověka a jeho chování (a jednání) umožňuje sociologii např́klad pochopit a vysvětlit kulturní a náboženskou rozmanitost $\mathrm{v}$ globálním rozměru, zohlednit význam symbolů, interpretací, ale také institucí apod. Náboženství se pak může jevit jako specifický způsob lidské interpretace sebe sama a světa. K těmto interpretacím dochází jak na základě tělesných (biologických) předpokladů, tak na základě specifické kulturní tradice. Každý konkrétní prvek náboženství v sobě tedy obsahuje část, která je univerzální (společná všem lidem ve všech kulturách, lidská univerzália), i část, která je specifická (je výsledkem individuálního vývoje a dané kulturní tradice).

11. Klíčem k pochopení této stránky člověka (a náboženství) je porozumění všem aspektům ontogeneze a socializace. Socializace (včetně socializace náboženské) vytváří základ interpretačních strategií a rámec obrazu světa. V tomto pohledu se člověk věřícím nerodí, věřícím se stává. A to bud' náboženskou socializací především v prostředí rodiny (ale také dalších sociálních sítí a struktur) nebo konverzí/alternací (vědomým přechodem $\mathrm{k}$ nějaké formě náboženství).

12. Tedy: na základě biologických a kulturních (včetně kognitivních, které jsou spojujícím článkem mezi biologickým a kulturním) předpokladů člověk aktivně vytváŕí (konstruuje) obraz světa. Ten se v dalším průběhu života více či méně proměňuje (respektive zůstává více či méně stejný), nebot' jedinec (i jako součást pospolitosti) konfrontuje (testuje) tento obraz světa s novými informacemi a svět (včetně chování jiných lidí) neustále interpretuje. Součástí tohoto obrazu světa mohou (ale také nemusí) být prvky, které badatelé nebo samotní věřící chápou jako „náboženské“. V globalizovaném a kulturně pluralitním světě se náboženství, respektive náboženská identita, stává stále více reflexivní a individualizovaná (což však nemusí znamenat privatizaci náboženství). 
13. K udržování určitého obrazu světa slouží jednotlivé struktury věrohodnosti, v nichž dochází k osobním setkáním, během nichž se prezentuje určitá interpretace světa a ta je v rámci této struktury líčena jako „normální“ a „nejlepší“, respektive věrohodná. Analýza fungování struktur věrohodnosti a způsobů chování, ke kterým v nich dochází, je vhodným nástrojem k pochopení náboženské socializace, reprodukce náboženství i procesů konverze.

\section{Závěr}

Předložený návrh rámcových základů biokulturní sociologické teorie náboženství představuje pokus o začlenění nových poznatků a konceptů kognitivních věd. Nejde však o proklamaci striktního a jednostranného biologického determinismu. Toto pojetí respektuje relativní samostatnost a svébytnost kultury, zdůrazňuje však nezbytnost zohlednění biologických, evolučních a kognitivních předpokladů vytváření kultury a náboženství. Respektuje přitom reflexivitu sociálního konstruování světa, přiznává jí však jen relativní platnost.

Kritičky a kritici tohoto pojetí jistě namítnou, že jde o silnou formu redukcionismu a návrat $\mathrm{k}$ realismu, pozitivismu a behaviorismu. Budou mít pravdu, ale jen částečně, nebot' navržený model začleňuje také fenomenologii, hermeneutiku, konstruktivismus a interpretativní př́ístup. Svým způsobem tak aplikuje modularitu lidského mozku na oblast sociální analýzy, nebot' proklamuje možnost (a nutnost) analyzovat každou část širokého náboženského života a náboženského chování specifickými nástroji, které nelze použít na jiné části; stejně jako je to u skládacího švýcarského nože, který obsahuje různé nástroje s různými funkcemi - na určitou část lze použít behaviorální analýzu (ptáme se po podobách náboženského chování) a na jinou interpretativní př́stup (ptáme se po významu, který člověk spojuje se svým náboženským jednáním).

Vzniká samožrejmě legitimní otázka, proč by měla sociologie jakýmkoliv způsobem reagovat na posuny $\mathrm{v}$ jiných vědách (včetně tzv. věd přírodních), zda začleňování poznatků jiných věd neruší identitu sociologie a zda ve svých důsledcích nevede k likvidaci sociologie jako svébytné vědecké disciplíny. Na takto položené otázky lze odpovědět také otázkou: Je vůbec možné nereflektovat poznatky, které jiným způsobem vysvětlují předmět našeho zájmu? Např́iklad je-li náboženství v sociologii většinou chápáno jako sociální konstrukt, nemusí nás zajímat, jak je toto konstruování náboženství ovlivněno evolucí, jak souvisí s biologickou stránkou člověka a jak je ovlivněno fungování lidské kognice?

Vzniká samozrejmě otázka, zda může sociologie (i v podobě biokulturní teorie náboženství) odpovídat na otázku po původu náboženství (tak, jak se o to snaží někteří kognitivní psychologové, antropologové a archeologové). Má $\mathrm{k}$ tomu vůbec sociologie vhodné analytické nástroje? Nebo se může ,jen“ zabývat sociokulturními důsledky a okolnostmi existence představ o nadpřirozených silách a zkoumat způsoby předávání těchto představ, popř́padě jejich souvislost se sociálními hierarchiemi a mocí apod.? Tuto otázku ponechávám v tomto textu záměrně otevřenou.

Max Weber končí své „Předznamenání k Sebraným statím k sociologii náboženstvi“ odstavcem, který nebývá př́liš často zmiňován, přesto je z mého pohledu nesmírně zajímavý, skoro až vizionářský. Poté, co se Weber zamýšlí nad otázkou „univerzálních dějin“a a klíčové 
úlohy západní kultury v nich a vymezuje některé klíčové prvky specifičnosti a ojedinělosti západní kultury, píše:

Konečně je potřeba promyslet také antropologickou stránku problému. Jestliže stále znova v Okcidentu a jen tam nacházíme určité druhy rozvíjejících se racionalizací, a to i v (zdánlivě) navzájem nezávisle se vyvíjejících oblastech životního způsobu, pak lze přirozeně předpokládat, že rozhodující podklad zde skýtají dědičné kvality. Pisatel se vyznává, že má osobně a subjektivně sklon k tomu vysoce oceňovat význam biologického dědictví. Avšak v této době, vzdor významným výkonům antropologické práce, nevidím žádnou cestu, abych co do míry a - především - co do způsobu a nasazení nějak exaktněji uchopil anebo jen hypoteticky naznačil jeho podíl na $z d e$ zkoumaném vývoji. Právě jednou z úloh sociologické a historické práce musí být, aby nejdříve odkryla pokud možno všechny ty vlivy a kauzální řetězce, které jsou uspokojivě vysvětlitelné prostřednictvím reakcí na osudy i prostředí. Teprve pak, a jestliže kromě toho srovnávací neurologie a psychologie ras dále pokročí za své dnes existující a v jednotlivostech mnohoslibné počátky, budeme snad smět doufat, že dostaneme uspokojivé výsledky také pro tento problém. (Weber 1989: 184)

Nuže, je potřeba říci, že neurologie (zvláště díky rozvoji digitálních technologií snímání činnosti mozku) a evoluční psychologie (díky začlenění kognitivní perspektivy) pokročily zvláště v posledních dvou desetiletích o výrazný krok a přinášejí poznatky a impulsy, které sociologie ignoruje. Otázky, které si tyto obory kladou, jsou jednoduché: Jak funguje lidská mysl? A proč takto funguje? Odpovědí je samožrejmě celá řada, avšak dovolím si zde výrazné zjednodušení a řeknu, že lidský mozek jako hardware lidské mysli funguje dnes stejně, jako fungoval v mladém paleolitu před 40000 až 10000 lety. A funguje tak díky vzniku sociální struktury (hierarchie) a komplikovaných sociálních vazeb. Kdyby dnes psal Durkheim své Elementárni formy náboženského života, nevybral by si jako př́klad „nejjednoduššího" náboženství totemismus, ale zaměřil by se na podoby náboženského života tvưrců jeskynních maleb v Altamiře.

Základní otázku předloženého textu bychom v jeho samotném závěru tedy mohli formulovat takto: Jestliže se fungování lidské mysli (stejně jako evoluční strategie) za posledních několik desítek tisíc let nezměnilo, proč při zkoumání náboženství v moderní společnosti tuto skutečnost nezohlednit? Rád bych na závěr vyjádřil zřetelně své přesvědčení, že biokulturní teorie náboženství neznamená popření teorie sekularizace a už vůbec ne teorie racionální volby. S teorií racionální volby má mnoho společného (model poměru nákladů a odměn, které mohou být materiální i nemateriální povahy), ale rozšiřuje racionální volbu o sféru emocionality i o oblast biologických a kognitivních předpokladů rozhodování. Teorii sekularizace přijímá jako způsob popisu strukturálních změn, ale také jako výzvu k testování pracovní hypotézy o náboženství jako výsledku evoluce, který však v dnešním světě přestal být adaptačně funkční.

Nic z toho, co dosavadní sociologie náboženství vyprodukovala, není tedy odvrženo. Jde pouze o rozširřrení perspektivy a postupné začleňování (a testování) dosavadních poznatků a konceptů v nové realitě, která je na jedné straně dána sociokulturním vývojem (globalizace) a na straně druhé rozvojem jednotlivých věd (biologických i sociálních). 


\section{Literatura}

ALLES, Gregory D. Religious Economies and Rational Choice. On Rodney Stark and Roger Finke Acts of Faith (2000). In STRAUSBERG, M. (ed.) Contemporary Theories of Religion. A Critical Companion. London - New York: Routledge, 2009, str. 83-98. ISBN 0415463475.

ATRAN, Scott. In Gods We Trust: The Evolutionary Landscape of Religion. New York: Oxford University Press, 2002. 348 s. ISBN 9780195178036.

BARRETT, Justin L. Why Would Anyone Believe in God? Lanham - Phymouth: AltaMira Press, 2004. 140 s. ISBN 9780759106673.

BARRETT, Louise; DUNBAR, Robin; LYCETT, John. Evoluční psychologie člověka. Praha: Portál, 2007. 551 s. ISBN 9788071789697.

BECKFORD, James. Social Theory and Religion. Cambridge - New York: Cambridge University Press, 2003. 252 s. ISBN 9780521774314.

BERGER, Peter L. The Sacred Canopy: Elements of a Sociological Theory of Religion. New York: Doubleday. 1967. $229 \mathrm{~s}$.

BEYER, Peter. Religion and Globalization. London: SAGE Publications, 1994. 250 s. ISBN 0803989164.

BEYER, Peter. Religions in Global Society. New York: Routledge, 2006. 323 s. ISBN 0415393183.

BEYER, Peter; BEAMAN, Lori (eds.). Religion, Globalization and Culture. Leiden: Brill, 2007.608 s. ISBN 9789004154070.

BOYER, Pascal. The Naturalness of Religious Ideas: A Cognitive Theory of Religion. Berkeley - Los Angeles - London: University of California Press, 1994. 323 s. ISBN 0520075595.

BOYER, Pascal. Religion Explained: The Evolutionary Origins of Religious Thought. New York: Basic Books, 2001. 375 s. ISBN 0465006957.

BRUCE, Steve. Religion in the Modern World: From Cathedral to Cults. Oxford: Oxford University Press, 1996. 256 s. ISBN 0198781512.

BRUCE, Steve. Choice nad Religion: A Critique of Rational Choice Theory. Oxford: Oxford University Press, 1999. 247 s. ISBN 9780198295846.

DOWNES, William. Language and Religion. A Journey into the Human Mind. Cambridge: Cambridge University Press, 2011. 288 s. ISBN 9780521792233.

EDELMAN, Gerard M. Neural Darwinism: The Theory of Neuronal Group Selection. New York: Basic Books, Inc., 1987. 371 s. ISBN 0465049346.

EDELMAN, Gerard M. The Remembered Present: A Biological Theory of Consciousness. New York: Basic Books, Inc., 1989. 346 s. ISBN 046506910X.

EDELMAN, Gerard M. Širší než obloha: Fenomenální dar vědomí. Praha - Litomyšl: Ladislav Horáček - Paseka, 2010. 156 s. ISBN 9788074320484.

EYSENCK, Michael W.; KEANE, Mark T. Kognitivni psychologie. Praha: Academia, 2008. 748 s. ISBN 9788020015594.

GURTHIE, Steward. Faces in the Clouds: A New Theory of Religion. New York: Oxford University Press, 1993. 336 s. ISBN 195069013.

HAVLÍČEK, Jakub. Cesty božstvev: Otázky interpretace náboženství a nacionalismu v moderním Japonsku. Brno: Masarykova univerzita, 2011. 222 s. ISBN 9788021055636.

CHOMSKY, Noam. Perspektivy moci. Praha: Karolinum, 1998. 323 s. ISBN 8071844918.

LAWSON, Thomas, E.; McCAULEY, Robert N. Rethinking Religion: Connecting Cognition and Culture. Cambridge - New York - Melbourne: Cambridge University Press, 1993. 194 s. ISBN 521373700.

LEWIS-WILLIAMS, David. Mysl v jeskyni: Vědomí a původ umění. Praha: Karolinum, 2007. 402 s. ISBN 9788020015181.

LEWIS-WILLIAMS, David; PEARCE, David. Uvnitř neolitické mysli: Vědomí, vesmír a řiše bohů, Praha: Academia, 2008. 398 s. ISBN 9788020016447. 
LIGHT, Timothy; WILSON, Brian C. Religion as a Human Capacity: A Festschrift in Honor of Thomas Lawson. Leiden - Boston: Brill, 2004. 462 s. ISBN 9004126767.

LUŽNÝ, Dušan. Náboženství a moderní společnost: Sociologické teorie modernizace a sekularizace. Brno: Masarykova univerzita, 1999. 183 s. ISBN 8021022248.

LUŽNÝ, Dušan. Globalizace a sociologie náboženství. In LUŽNÝ, D., VÁCLAVÍK, D. a kol. Individualizace, náboženství a identita: Poznámky k současné sociologii náboženství. Praha: Malvern, 2010a, str. 13-40. ISBN 9788086702698.

LUŽNÝ, Dušan. Základy perspektivy sociologie náboženství. In LUŽNÝ, D., VÁCLAVÍK, D. a kol. Individualizace, náboženství a identita: Poznámky k současné sociologii náboženství. Praha: Malvern, 2010b, str. 343-347. ISBN 9788086702698.

LUŽNÝ, Dušan. Questions of Contemporary Sociology of Religion: Individualization and Globalization as Basis of Contemporary Cultural and Religious Pluralism. In KUPISIŃSKI, Z., GRODŹ, S. (eds.) Pluralizm kulturowy i religijny wspótczesnego świata. Lublin: Wydawnictwo KUL, 2010c, str. 403-413. ISBN 9788377021057.

LUŽNÝ, Dušan. Hledání „,nové“ sociologie náboženství: Na okraj diskuse o redukci a „redukcionismu“ v dosavadní sociologii náboženství. Biograf, roč. 2011, č. 54. ISSN 12115770.

MARTIN, David. A General Theory of Secularization. Oxford: Blackwell, 1978. 353 s. ISBN 0751201944.

McNAMARA, Patrick (ed.). Where God and Science Meet: How Brain and Evolutionary Studies Alter Our Understanding of Religion I.-III. Westport: Praeger Publishers, 2006. 294 s. (vol. I), 264 s. (vol. II), 304 s. (vol. III). ISBN 0275987892 (vol. I), 0275987906 (vol. II), 0275987914 (vol. III).

McNAMARA, Patrick. The Neuroscience of Religious Experience. New York: Cambridge University Press, 2009. $301 \mathrm{~s}$. ISBN 9780521889582.

NEWBERG, Andrew; D'AQUILI, Eugene; RAUSE, Vince. Why God Won 't Go Away: Brain Science and the Biology of Belief. New York: Free Press, 2001. 234 s. ISBN 034544034X.

PYYSIÄINEN, Ilkka. How Religion Works: Toward a New Cognitive Science of Religion. Leiden - Boston - Köln: Brill, 2003. 272 s. ISBN 9004123199.

ROBERTSON, Roland, 1992. Globalization: Social Theory and Global Culture. London: SAGE, 1992. 211 s. ISBN 0803981872.

STARK, Rodney; BAINBRIDGE, William Sims. The Future of Religion, Berkeley: University of California Press, 1985. 571 s. ISBN 0520057317.

STARK, Rodney; BAINBRIDGE, William Sims. A Theory of Religion, New York: Lang, 1987. 386 s. ISBN 0813523303.

STARK, Rodney. Secularization, R.I.P. Sociology of Religion, 1999, roč. 60, č. 3, s. 249-273. ISSN 1069-4404.

STARK, Rodney; FINKE, Roger. Acts of Faith: Explaining the Human Side of Religion. Berkeley: University of California Press, 2000. 343 s. ISBN 9780520222021.

STERNBERG, Robert, J. Kognitivní psychologie. Praha: Portál, 2009. 636 s. ISBN 9788073676384.

STRAUSBERG, Michael (ed.) Contemporary Theories of Religion: A Critical Companion. London New York: Routledge, 2009. 309 s. ISBN 0415463475.

TURNER, Bryan S. The Two Faces of Sociology: Global or National? In FEATHERSTONE M. (ed.) Global Culture. Nationalism, Globalization and Modernity. London - Thousand Oaks - New Delhi: SAGE, 1990, s. 343-358, ISBN 080383220.

TURNER, Bryan S. Religion and Social Theory. London: SAGE 1991. 264 s. ISBN 080398569X.

TURNER, Bryan S. Orientalism, Postmodernism and Globalism. London: Routledge, 1994. 228 s. ISBN 0415108624.

YOUNG, Lawrence A. Rational Choice Theory and Religion: Summary and Assessment. New York: Routledge, 1997. 187 s. ISBN 0415911923. 
VIDO, Roman. Konec velkého vyprávění: Sekularizace v sociologické perspektivě. Brno: CDK, 2012. 348 s. ISBN 9788073252663.

VÁNĚ, Jan. Sociologie náboženství v době nejen postmoderní. In LUŽNÝ, D., VÁCLAVÍK, D. a kol. Individualizace, náboženství a identita: Poznámky k současné sociologii náboženství. Praha: Malvern, 2010, s. 64-86. ISBN 9788086702698.

WEBER, Max. Metodologie, sociologie a politika, Praha: Oikoymenh, 1989. 354 s. ISBN 9788072983896.

WIEBE, Donald. Roots in the Brain: On David Lewis-Williams and David Pearce Inside the Neolitic Mind (2005). In STRAUSBERG, M. (ed.) Contemporary Theories of Religion: A Critical Companion. London - New York: Routledge, 2009, s. 195-208. ISBN 0415463475.

WIEBE, Donald. Význam přirozené zkušenosti „,nepřirozeného“ světa pro otázku vzniku náboženství. Religio, roč. 2011, 19, č. 1, s. 3-26. ISSN 12103640.

WILSON, Bryan. Religion in Sociological Perspective. Oxford - New York: Oxford University Press, 1992. 187 s. ISBN 0198266642.

WILSON, Edward O. Konsilience: Jednota vědění. Praha: Nakladatelství Lidové noviny, 1999. 379 s. ISBN 8071063215.

WILSON, Edward O. O lidské prrirozenosti. Praha: Nakladatelství Lidové noviny, 1993. 246 s. ISBN 8071060763.

WHITEHOUSE, Harvey. Arguments and Icons: Divergent Modes of Religiosity. New York: Oxford University Press, 2000. 216 s. ISBN 0198234147.

WHITEHOUSE, Harvey. Modes of Religiosity. A Cognitive Theory of Religious Transmission. Walnut Creek: AltaMira Press, 2004. 193 s. ISBN 0759106150.

WHITEHOUSE, Harvey. Teorie dvou modů náboženskosti. Religio: revue pro religionistiku, 2009, roč. 17, č. 2, s. 209-230. ISSN 12103640.

WINKELMAN, Michael; BAKER, John R. Supernatural as Natural: A Biocultural Approach to Religion. Upper Saddle River: Pearson Prentice Hall, 2010. 353 s. ISBN 0131893033.

\section{Autor}

Dušan Lužný působí na Katedře sociologie a andragogiky Filozofické fakulty Univerzity Palackého v Olomouci a zároveň na Katedře sociologie Filozofické fakulty Západočeské univerzity v Plzni a na Katedře filozofie Filozofické fakulty Masarykovy univerzity v Brně. Zaměřuje se na oblast sociologie náboženství, výzkum nových náboženských hnutí a na sociologickou teorii. K tomuto tématu publikoval několik monografií (např́íklad Nová náboženská hnutí, Masarykova Univerzita: Brno, 1997; Náboženstvi a moderní společnost. Sociologické teorie modernizace a sekularizace, Masarykova univerzita: Brno 1999; Hledání ztracené jednoty. Průniky nových náboženství a ekologie, Masarykova univerzita: Brno 2004; Sociologie náboženství [společně se Zdeňkem Nešporem], Portál: Praha 2007; Oddaní Kršny. Hnutí Haré Kršna v pohledu sociálních věd [společně s Milanem Fujdou], Západočeská univerzita v Plzni: Plzeň 2010) a řadu odborných studií.

Kontakt: dusan.luzny@upol.cz 